\title{
Special Education Teachers' Narratives on Literacy Support for Bilingual Students with Dyslexia in Swedish Compulsory Schools
}

\author{
Niloufar Jalali-Moghadam ${ }^{\star}$, and Christina Hedman \\ Department of Psychology, Orebro University, Sweden (NFM); Department of Language \\ Education, Stockholm University, Sweden (CH)
}

\begin{abstract}
The aim of the study is to investigate how special education teachers talk about their teaching in relation to bilingual students with dyslexia within Swedish compulsory schools. Data consist of transcripts from in-depth interviews with 15 special education teachers. According to the teacher narratives, the special education services appeared to be biased against bilingual students, as the support provided to bilingual students with dyslexia was revealed to be more or less the same as that provided to monolingual Swedish-speaking students with dyslexia. This bias is discussed in relation to the notion of difference blindness as well as in relation to practical constraints. Nevertheless, the teachers strongly advocated collaborative work with mother tongue teachers in order to facilitate dyslexia identification in bilingual students and to gain a more comprehensive picture of their language and literacy competencies, which is a desire that contrasts and contests a pedagogical monolingual master model within special education services.
\end{abstract}

Keywords: Bilingualism; bilingual education policy; literacy; special education

Received: November 2015; Accepted: April 2016; Published: June 2016

\section{Introduction}

This study takes its standpoint in the egalitarian perspectives of educational support vis-à-vis students with reading and writing difficulties as expressed in the Swedish Education Act, where it is stated that students who do not attain the goals of the syllabus are entitled to special education support (Utbildningsdepartementet, 2010, p. 800, Ch. 3, 7-9\$). It has most commonly been interpreted as special education services delivered by special education teachers within a school context (Fouganthine, 2012), which implies that a substantial responsibility for the goal attainment of children with a range of possible learning disabilities, such as dyslexia,

${ }^{\star}$ Correspondence to: Christina Hedman, Department of Language Education, Stockholm University, S-106 91 Stockholm, Sweden. E-mail: christina.hedman@isd.su.se 
is assigned to the special education teachers (see Nilholm, 2007, for further discussions on the role of special education teachers). The current study focuses on in-depth interviews with special education teachers and their narratives regarding their own teaching in relation to bilingual students with dyslexia, involving literacy support as well as dyslexia identification procedures. This is in line with the concept of teacher cognition (e.g. Borg, 2006), where possible influences of teacher perceptions and pedagogical decisions upon pedagogical practices are under consideration. Thus, the study aims to contribute with insights about special education teachers' thoughts on educational support for bilingual students with dyslexia within the compulsory Swedish school - of which we know very little from research.

\subsection{Bilingual education policy in Sweden: Pluralistic intentions versus a monolingual ideology}

In Sweden, there is relatively strong legal support for bilingual children from minority language backgrounds with 'mother tongues' other than Swedish regarding their rights to bilingual development and language use (the term bilingual here refers to the use of two or more languages). For example, the Swedish Language Act (Kulturdepartementet, 2009) states that all Swedish residents have the right to develop and use, not only Swedish, but also other mother tongues. The curriculum for compulsory school states that the education should be adapted to the needs of each individual student and based on his/her languages, background knowledge, and previous experiences (Utbildningsdepartementet, 2010:800). Bilingual students from minority language backgrounds form a heterogeneous category and the premises for language and literacy acquisition and learning vary greatly between individuals (e.g. Hyltenstam \& Milani, 2012). For example, age of arrival, previous schooling, and literacy in the first language (other than Swedish) as well as socioeconomic background are important variables for second language learning and school achievement (e.g. Abrahamsson \& Bylund, 2012; Axelsson \& Magnusson, 2012).

Furthermore, the Swedish Education Act (Utbildningsdepartementet 2010, p. 800) regulates the right to mother tongue instruction (MTI), that is, the teaching of minority languages as a subject in the Swedish school curriculum, based on if the child has a legal guardian who speaks another mother tongue than Swedish, if the child uses the mother tongue for communication on a daily basis at home, and if the child has basic knowledge of the language in question. This legal right was first introduced with the enactment of the Home Language Reform in 1977 (see Hyltenstam \& Milani, 2012). About 23\% of the students in compulsory school are entitled to MTI (Statistics Sweden, 2014). However, MTI has struggled with implementation problems over the years and is a marginalized practice within the Swedish school system (Ganuza \& Hedman, 2015). For example, MTI has strict limited time allotted to it (often only 40 minutes per week) and is most often scheduled outside the regular school hours. Meanwhile, a form of subject support in the students' first language known as study guidance (Swedish: studiehandledning) may be offered within the mainstream curriculum. This support, although limited with 
regard to the time allotted it, is available to newly arrived students, that is, to students who have arrived in Sweden within a 4-year period of time (Nilsson \& Axelsson, 2013; Utbildningsdepartementet, 2013). In addition, the school subject Swedish as a second language, a parallel track to the school subject Swedish, is also part of the Swedish bilingual education policy. The term second language (L2) here refers to a language learned later as compared to a first language (L1 or 'mother tongue'), which is a language learned from birth (although individuals can develop more than one L1 and L2). This L1-L2 distinction has, however, been criticized for being Eurocentric and based on a monolingual norm (e.g. Bagga-Gupta, 2004).

It is particularly noteworthy that although Swedish language education policy reflects pluralistic language ideological intentions, the educational field and its institutions are not necessarily reflective of such a language ideology (cf. Gogolin's analysis of school as an institution deeply rooted in a monolingual habitus, Gogolin, 1994, in Busch, 2014, p. 22; cf. also the many implementation problems of the Swedish language policy, Hyltenstam \& Milani, 2012). Hyltenstam and Milani (2012) argue that there has been a mismatch between pluralistic language ideological intentions as expressed in Swedish bilingual education policy, and the assimilative, monolingual language ideology reflected in public and political debate since the enactment of the Home Language Reform in the 1970s. According to Kroskrity (2006) a dominant (monolingual norm-based) language ideology may be reflected both in articulated beliefs and attitudes as well as embedded in people's behavior and practices (as shown in a Swedish school context, e.g. Haglund, 2005). A dominant monolingual ideology may even take the expression of difference blindness (Kubota, 2004). According to Runfors (2009, see also Taylor, 1999), this term derives from a vision of the welfare state where all citizens are treated equally regardless of origin and where differences are downplayed in order to avoid creating undesirable social hierarchies. Lindberg (2009) argues, however, that contrary to its good intention, a difference blind pedagogical practice is problematic as it is modeled on first-language speakers of the language of instruction only. Thus, language instructional needs for bilingual students, in terms of learning and learning through the language of instruction as a second language, are neglected, and by not providing instruction that more closely meets the needs of bilingual learners, a school achievement gap may widen. Moreover, Lindberg (2009) argues that difference blindness is part of the Swedish educational system in general.

\subsection{Identifying dyslexia in bilingual students}

As opposed to the broad term reading and writing difficulties, which is associated with various explanatory causes, the term (developmental) dyslexia refers to more specific reading and writing difficulties with a neurobiological cause. However, definitions of dyslexia vary over time and contexts. An early 'classic' definition of dyslexia was coined in 1968 by the World Federation of Neurology, which stated that dyslexia is 'A disorder manifested by difficulty in learning to read despite conventional instruction, adequate intelligence and socio-cultural opportunity. It is dependent on fundamental cognitive disabilities which are frequently constitutional in origin'. In this definition, 
a reading-IQ performance discrepancy is assumed, which is one reason why IQ testing has been frequently used in many schools for identifying dyslexia (Stanovich, 1994). This definition specifies, however, neither what characterizes dyslexic difficulties nor what their underlying causes are. Moreover, the extensive use of IQ tests has been criticized, particularly in relation to bilingual children from minority linguistic or cultural backgrounds, who run the risk of having their IQ underestimated (Cline \& Reason, 1993; Phil, 2010) and consequently being denied appropriate literacy support (e.g. Frederickson \& Frith, 1998; Mortimore et al., 2012).

According to a more recent and widely accepted phonological explanatory model of dyslexia (see definition from the International Dyslexia Association, IDA, Lyon, Shaywitz, \& Shaywitz, 2003), IQ testing is not considered to be critical for determining difficulties with phonological processing (e.g. Gus \& Samuelsson, 2002).

Dyslexia is a specific learning disability that is neurobiological in origin. It is characterized by difficulties with accurate and/or fluent word recognition and by poor spelling and decoding abilities. These difficulties typically result from a deficit in the phonological component of language that is often unexpected in relation to other cognitive abilities and the provision of effective classroom instruction. Secondary consequences may include problems in reading comprehension and reduced reading experience that can impede growth of vocabulary and background knowledge. (IDA-definition, Lyon et al., 2003, p. 2).

This definition is in line with a model on reading in which reading comprehension is proposed to be the product of two main components: word recognition and listening comprehension (the Simple View of Reading, Gough, Hoover, \& Peterson, 1996). According to this model, individuals with dyslexia have specific difficulties with the word decoding component. Verhoeven and van Leeuwe (2012) analyzed reading development in both L1 and L2 learners in relation to the Simple View of Reading and found that reading comprehension in an L2 was more dependent on oral language proficiency as compared to L1 reading. Thus, from the Simple View of Reading perspective, both word decoding and comprehension processes are likely to be challenging for L2 learners with dyslexia.

However, it is not clear to what extent a phonological explanatory model provides adequate criteria for identification in various languages, as manifestation of dyslexia may vary across languages (Ziegler \& Goswami, 2005). Thus, according to a scriptdependent view, '[a]n assessment in one language cannot be used as evidence of dyslexic difficulties in another' (Mortimore et al., 2012, p. 30). A Swedish smallscale study of Spanish- and Swedish-speaking secondary school students arrived at a similar conclusion that both languages needed to be taken into account for valid dyslexia identification in the bilingual students (Hedman, 2009). All tests were carried out in both languages; in addition, the test norms were based on bilingual students who had been matched based on a number of criteria relevant for literacy development. However, in accordance with a central processing theory, in which 
underlying phonological processing difficulties are seen as universal, the need for assessment in L1 is downplayed when it comes to assessment of phonological processing, phonological short-term memory, speed of processing, and rapid naming (e.g. Miller Guron \& Lundberg, 2003; cf. Mortimore et al., 2012). For example, Miller Guron and Lundberg (Miller Guron \& Lundberg, 2003) found that phonological assessment in the language being taught (Swedish) was a valid strategy for identifying dyslexia among bilingual secondary school students who had spent their entire schooling in Sweden. This conclusion was based on tests in Swedish only.

The motivation to use measures in a students' L1 may also be decreased by the lack of tests in the L1 as well as lack of suitable assessors (Geva \& Wade-Woolley, 2004; Mortimore et al., 2012). In Norway, however, screening materials that assess vocabulary, reading fluency, and reading comprehension have been developed in various minority languages (see Bøyesen, 2008). This material has also become available in a Swedish context ${ }^{1}$ where the aim is to provide a tool for identifying dyslexia in bilingual students as well as the learner's stage of reading development in the minority language. The material is intended to be used by mother tongue teachers in collaboration with special education teachers, where the mother tongue teachers are expected to assess reading in the minority language and the special education teachers are expected to assess the students' reading and writing in Swedish. Dynamic test procedures that are 'developed and used to assess learning potential rather than present attainment' have also been highlighted as advantageous for valid dyslexia diagnosis in younger children (Gellert \& Elbro, in press), as well as in adults (Elbro, Daugaard, \& Gellert, 2012). In these dynamic assessment procedures, the ability to acquire the alphabetic principle is measured. In Elbro et al. (2012), the test takers were introduced to a set of (three) new letter shapes and their sounds. The task was to learn to read the letter shapes as well as non-words composed of these new 'letters'. Thus, in the dynamic reading test, the influence of variables such as L2 vocabulary knowledge is diminished. One limitation is, however, that the test is not susceptible to non-alphabetic orthographies (Elbro et al., 2012, p. 183).

In a research report based on a study of British school contexts, Mortimore et al. (2012, p. 29) express a general concern with a pedagogical 'monolingual master model' found in schools, not only in relation to dyslexia assessment procedures but also in relation to bilingual students' linguistic and cultural backgrounds in general. In a pedagogical monolingual master model, the languages and background knowledge of bilingual students are neglected as the pedagogy is based on a monolingual majority language-speaking norm (cf. the notion of difference blindness, Kubota, 2004, as well as the notion of a monolingual habitus, Gogolin, 1994). Mortimore et al. (2012) emphasize the need for another school ethos, where, ideally, there is space for tests in other languages than the language of instruction and where more comprehensive assessments are used in order to ensure that information about

\footnotetext{
${ }^{1}$ Flerspråkig kartläggning av avkodning och läsning - ett kartläggningsmaterial [Multilingual assessment of decoding and reading - an assessment material] www.spsm.se
} 
the child's entire linguistic repertoire is taken into account. Such a school ethos is in line with the general language policy in the Swedish curriculum (Utbildningsdepartementet, 2011, p. 8). It is also in line with L2 research showing that students with strong language and literacy competencies in their L1 will benefit from these when developing such competencies in their L2 (e.g. Cummins, 2000), in accordance with the language interdependence hypothesis (Cummins, 1979).

\subsection{Literacy support for bilingual students with dyslexia}

There is a vast collection of research literature on various forms of literacy support that aim to facilitate the development of basic literacy skills for students with dyslexia in general; however, not all of the approaches are evaluated in satisfactory ways. According to the Swedish Council on Health Technology Assessment (Statens beredning för medicinsk utvärdering, 2014, p. 153), evidence has been found for the efficacy of structured interventions with regard to phoneme-grapheme mapping on reading, spelling, reading comprehension, reading speed, and phonological awareness. These conclusions are similar to those found in an earlier report from the Swedish Research Council (Myrberg, 2007), in which the importance of phonological awareness training is emphasized. Information and communication technology (ICT) is also considered in the aforementioned reports as, for example, computeraided programs can be used to compensate for dyslexic difficulties (such as spelling and reading difficulties) or as didactic tools for the development of certain skills such as phonological awareness skills (Myrberg, 2007). In order for these computer-aided programs to be successful, however, teachers need to be actively involved (Myrberg, 2007). In the report from the Swedish Research Council, the special education teachers' important role in dyslexic children's literacy development is highlighted, particularly the value of dyslexic children's access to individual or small-group lessons with special education teachers. There is less research literature regarding the support for bilingual students with dyslexia that moves beyond the aforementioned focus on basic literacy skills. However, Sunderland, Klein, Savinson, and Partridge (1997) point out the importance of using teaching strategies that are meaningful, structured, multimodal, and explicit, which are important guidelines for all students learning in a second language, and also the importance of learning materials that take into account the students' linguistic and cultural backgrounds (see also Deponio, Landon, Mullin, \& Reid, 2000; cf. work on literacy development in L2 learners in general, Gibbons, 2002). Likewise, these types of educational guidelines are found in the British research report by Mortimore et al. (2012, p. 104), where one conclusion is that literacy support must include meaningful texts and vocabulary in both L1 and L2, comprehension strategies as well as active engagement and interaction. In this report, it is also recommended that teachers and teacher assistants with knowledge of minority languages are recruited in order to facilitate literacy development and learning. That would follow the logic of the interdependence of language competencies (Cummins, 1979), which implies that the development of literacy skills in one language positively affects the development of literacy skills in another. There is evidence of such cross-linguistic relations both concerning basic 
literacy skills (e.g. Shakkour, 2014; see also Ganuza \& Hedman, under review) and the type of literacy knowledge required for learning in various school subjects (e.g. Cummins, 2000).

\section{Aim}

The aim of the current study is to investigate how special education teachers talk about their teaching in relation to bilingual students with Swedish as their second language within Swedish compulsory schools. Questions to be addressed are:

1. What type of support is offered regarding both literacy support and dyslexia identification procedures?

2. What are the perceived practical and structural constraints?

3. Does the type of support offered to bilingual L2 Swedish-speaking students with dyslexia differ from that provided to 'monolingual' L1 Swedish-speaking students with dyslexia?

Answers to these questions are expected to shed light on how the teachers relate to the general bilingual education policy expressed in the curriculum (Utbildningsdepartementet, 2011, p. 8).

\section{Materials and methods}

\subsection{Selection of teachers for the in-depth interviews}

In the current study, data include in-depth interviews with 15 special education teachers who worked in compulsory schools with a high proportion of bilingual students. The teachers were first approached with an e-mail (originally sent out to approximately 150 special education teachers in Swedish middle- to large-sized cities) where the teachers were informed about the study. A short questionnaire was attached to the e-mail which included open-ended questions about the special education support in use for students with dyslexia and whether any additional support was offered to bilingual students with dyslexia, what the objectives behind the educational support in use were, and the perceived shortcomings of the special education services, as well as suggested improvements. Of all the teachers, 35 answered the questionnaire, and 15 of these teachers (12 females and 3 males) agreed to take part in an in-depth interview, which are the data in focus of this study. All of the 15 teachers had graduated from Swedish universities and the years they had been working within special education varied between 2 and 37 years. The study encompassed both types of special education teachers found in Swedish special education services, that is, 'special pedagogues' (specialpedagoger) and 'special teachers' ${ }^{2}$ (speciallärare), where one distinction is that the special pedagogues are trained to have a more

\footnotetext{
${ }^{2}$ The same English terms 'special pedagogue' and 'special teacher' are used as in Takala and Ahl (2014).
} 
consulting role as compared with the special teachers (Takala \& Ahl, 2014; Utbildningsdepartementet, 2007:638).

\subsection{The in-depth interviews}

In the in-depth interviews, the teachers' views on their current educational practices vis-à-vis bilingual students with documented dyslexia or students who were thought to be dyslexic (henceforth referred to as 'at-risk dyslexic' students) were further explored. The interviews were conducted by the first author, who chose to use English during the interviews, as she felt more comfortable speaking English. The teachers indicated that they did not feel uncomfortable with the researcher speaking English as long as they were free to speak Swedish, which they all did. Swedish was also used by the researcher for clarifications. The interviews were conducted in the teachers' schools and lasted about 1 hour. The interviews were focused on the research questions outlined above, which were prompted with initial questions such as:

1. How do you work with students with dyslexia?

2. Do you work with bilingual students (with Swedish as their second language)?

3. Do the bilingual students need additional support? What type?

4. What type of support do you find to be most efficient for literacy development?

5. What do you find to be the shortcomings (of $\mathrm{X}$ type of help)?

6. What additional type of support would be desirable?

The answers to these questions were then followed up by additional questions. In the interviews, it was possible for the teachers to specify more closely what they meant by 'bilingual students'. The teachers generally used this term to refer to minority language-speaking students who spoke Swedish as their second language. The teachers could also specifically refer to 'newly arrived students'. All teachers expressed happiness and even gratitude about the opportunity to talk about their daily work and did not mind the audio recording.

\subsection{A qualitative analysis of the narratives}

The audio recordings were transcribed and the transcripts were analyzed qualitatively employing QSR Nvivo Software, in which the process of grouping single 'voices' into larger themes is facilitated. The analysis of the data is influenced by a narrative inquiry approach (see Clandinin \& Connolly, 2001), in which people's voices are represented and interpreted. The current analysis is also influenced by a social constructionist perspective, where societal norms and views on what is considered to be accepted or not are thought to have bearing on the narratives. A narrative inquiry approach raises questions about validity, for example, regarding to what extent the teachers' narratives represent 'facts' (Hunter, 2009, p. 44). A premise from a social constructionist's perspective is, however, that the narratives are viewed as context dependent and not representing one generalizable 'truth' (Hunter, 2009). All the same, 'representing and interpreting another's voice is not a 
simple task and needs to be done with respect and humility' (Hunter, 2009, p. 50). It is important to note that the results from this study are intended to reflect perceptions of the teacher/s in this particular study and cannot easily be generalized to the special education services in Sweden as whole. In the following section, the teachers' responses are presented and discussed in accordance with the main themes of interest in the interviews:

1. Theme I: Type of support (addressing research questions 1 and 3)

2. Theme II: Practical and structural constraints (addressing research question 2).

Research question 3 (reported support to the bilingual students as compared to the monolingual Swedish-speaking students) is discussed in more depth in the final discussion.

\section{Results}

\subsection{Theme I: Type of support}

In the interviews, the teachers did not specifically express their views on dyslexia or their views on theoretical underpinnings of the condition. However, their thoughts on intervention and dyslexia testing procedures revealed a clear influence of the phonological explanatory model. Accordingly, training of phonological awareness appeared as one of the most prominent and frequently used methods to facilitate development of basic literacy skills for students with dyslexia. The phonological awareness training was thought to facilitate the students' reading and spelling in Swedish, and the special education teachers found it particularly advantageous to focus on intensive and early training of phonological awareness (cf. Statens beredning för medicinsk utvärdering, 2014). As mentioned earlier, in the interviews, the teachers seemed to use the term bilingual students interchangeably with second language learners of Swedish. The teachers either explicitly talked about second language learners and/or referred to the bilingual students as learners of Swedish and even sometimes as lacking Swedish language skills as compared to monolingual Swedish-speaking students, particularly with regard to reading comprehension (see Excerpt 1). Thus, bilingual students, as L2 learners of Swedish, seemed to be perceived as a specific pedagogical challenge to the teachers. Although an emphasis of the special education services was on phonological awareness training and work on phoneme-grapheme mapping in reading and spelling, it was pointed out by teacher Johanna (Excerpt 1) that an emphasis on technical aspects of reading was not sufficient for the bilingual students' literacy development. As illustrated in Excerpt $1,{ }^{3}$ teacher Johanna ${ }^{4}$ found that it was unwise to approach a bilingual 'at-risk' dyslexic student's reading as an exclusively technical task.

\footnotetext{
${ }^{3}$ Interview excerpts have been translated from Swedish into English by the authors with the intent of preserving the translations close to the original regarding both content and language.

${ }^{4}$ All names are pseudonyms.
} 
Excerpt 1, interview with teacher Johanna:

Researcher: What is your impression or idea of how common dyslexic problems are?

Teacher Johanna: Well it feels very common today, something that is detected much earlier. [...] For bilingual students, it is more difficult. So it is not enough to see if you can read technically, as comprehension is also needed. Previously I did not notice this so clearly. I could see that there were some technical difficulties with the reading but now I am more attentive.

Instead, teacher Johanna emphasized the importance of working with the bilingual students' text comprehension in Swedish, or more specifically with students' word knowledge in a deeper sense (cf. the notion of vocabulary depth, e.g. Verhallen \& Schoonen, 1993, and the previous discussion on the Simple View of Reading in relation to L2 learners with dyslexia). The importance of vocabulary was confirmed by teacher Rasmus who thought that it might not be enough to work with word knowledge in Swedish only, particularly not only with the newly arrived bilingual students but also with word knowledge in the bilingual students' other languages (cf. the emphasis on L1-support in Mortimore et al., 2012).

The focus on phonological awareness training did not appear to exclude other teaching approaches, as the advantages of combining the phonologically based training with other types of language awareness training were also emphasized, such as focusing on syntactic aspects of the (Swedish) language. Furthermore, the special education teachers reported that they helped the students with text reading in Swedish. For example, the students were asked to read various booklets, or the teacher read aloud to the students. The text reading exercises could also consist of the students working with an e-book or with various computer programs. There was a general emphasis on multimodal approaches to reading, where the idea is to integrate sensory modalities such as sight and sound.

In addition, a substantial amount of time was reported to be spent on the administered reading and writing tests, as the special education teachers were responsible for regular class screenings of basic literacy skills. The advisory part of the special education services addressed a variety of issues. For example, the special education teachers gave the class teachers advice about which students would benefit from longer examination time and/or from working more regularly in quiet rooms and with what type of material (computer-based or not). Apart from this advisory work in class, which in most cases was based on previous assessment procedures, special education support was delivered both individually and in small groups. The use of preliminary 'diagnostic tests' in the lower grades in order to identify the 'at-risk' dyslexic children was perceived as a policy embedded in the educational system. The objective of these screening practices, that is, to facilitate early diagnosis of dyslexia, was highly supported by the special education teachers, as they firmly emphasized the value of an early diagnosis as necessary to provide help 'on time' (see Excerpt 2). 
Excerpt 2, interview with teacher Jennifer:

Researcher: So what is most efficient?

Teacher Jennifer: The biggest help is to give them help on time, when we see that it already starts in grade one with the writing that we do there. When we see that those students stick out, then of course, then I think support must be delivered immediately.

Yet, teacher Malin problematized these screening practices of reading and writing development as she thought that the tests were less efficient for bilingual students with Swedish as a second language (see Excerpt 3), considering the fact that the language of the tests is Swedish.

Excerpt 3, interview with teacher Malin:

These diagnostic tests we use to measure students' reading comprehension and decoding abilities, these are made for speakers of Swedish and when we use them for students who have Swedish as a second language they do not measure what they are supposed to measure. Therefore, they [students with Swedish as a second language] always get worse results and this is not because they have reading and writing difficulties, but because they have difficulties with the texts.

None of the teachers mentioned the use of IQ tests as a practice in use or as a possible problem. IQ testing is, however, not part of the special education teachers' practices because such test procedures are carried out by psychologists.

A general perception was that it took a longer time to discover dyslexia in bilingual students as compared with monolingual Swedish-speaking students. This was explained by the perceived difficulties in ascertaining the origins of the bilingual students' reading and/or writing problems; whether the difficulties were due to the fact that the students were second language learners of Swedish or whether the students actually had underlying dyslexic difficulties (cf. Hedman, 2009; Hedman, 2012).

\subsection{Theme II: Practical and structural constraints}

For purposes of early identification of dyslexia in bilingual students, the special education teachers expressed a strong desire to work more collaboratively with other teachers and particularly with mother tongue teachers (cf. Meynert, 2014, regarding positive views on collaboration in special education settings). For example, teacher Erik thought that the mother tongue teachers' perspectives and knowledge were relevant for him to take into consideration. The special education teachers expressed that collaboration with mother tongue teachers could potentially facilitate earlier identification of dyslexia in bilingual students and that the mother tongue teachers could provide a more comprehensive picture of the reading and writing development of a bilingual student, involving other languages than Swedish (cf. Morgan, 2014). This collaboration was, however, difficult to achieve in practice. The teachers seldom collaborated with mother tongue teachers mainly due to practical organizational reasons, as the mother tongue teachers worked in various schools and often in late 
afternoons (cf. Ganuza \& Hedman, 2015), which allowed for few opportunities to meet (see Excerpt 4). In this sense, there was a discrepancy between how the teachers valued such collaborative work and their actual possibilities to collaborate as described in the interviews (e.g. Borg, 2006).

Excerpt 4, interview with teacher Karin:

Researcher: So, the schools are then aware of the problems?

Teacher Karin: In general, there is a lack of collaboration with the mother tongue teachers. There is no good organization to it, mother tongue teachers go here and there, everywhere, and it is not possible to collaborate with a teacher who goes to ten different schools.

As the mother tongue teachers (or most of them) are not employed by the schools but affiliated with other units (cf. Skolverket, 2008), these organizational differences were found to further discourage collaboration, as expressed in Excerpt 5.

\section{Excerpt 5, interview with teacher Erik:}

Researcher: Do you collaborate with mother tongue teachers?

Teacher Erik: They come and copy some things and then disappear. [...] Mother tongue teachers have another boss in the city, so we do not have the right to request anything from them and they do not have time to sit and talk with us.

This is in line with previous findings where MTI has been found to be poorly integrated within the mainstream school (e.g. Ganuza \& Hedman, 2015; Skolverket, 2008). It is noteworthy that none of the teachers reported having any experience of using the assessment material based on various minority languages, which presupposes collaboration with a mother tongue teacher. This may be due to the obstacles to collaboration as outlined above.

Moreover, as no extra time was said to be allocated for bilingual students with Swedish as a second language, the special education teachers did not think that these students received the amount of help that they actually needed. For example, teacher Jennifer expressed that she did not have enough time for her students (Excerpt 6) and expressed her frustration over the fact that she is the only special education teacher in a primary school with nearly 200 students.

\section{Excerpt 6, interview with teacher Jennifer:}

There is a lack of time. If I want to do something I can, but there is not enough time. It is only me in the whole school.

Emanuelsson (2001) argues that the issue of lack of time can be interpreted as a sign of the low status accorded teachers' work in general. Some of the special education teachers in the current study believed that increased time was particularly necessary for the bilingual students (see Excerpt 7). 
Excerpt 7, interview with teacher Alexandra:

The most difficult thing is to invest a lot of extra time because [bilingual] students with reading and writing difficulties require a lot of extra time.

A recurring explanation was that the special education teachers indicated that it took a longer time to identify and follow up on the origins of the bilingual students' reading and writing difficulties, and that it was found to be difficult to manage this task on their own. Teacher Johanna also found that it took time to motivate the students and to 'help them see the future'.

Furthermore, a perceived lack of knowledge regarding reading and writing difficulties and special education services among school staff in general was viewed as a substantial obstacle to collaboration (cf. Dockrell \& Lindsay, 2001; Thygesen, Briseid, Tveit, Cameron, \& Kovac, 2011), and that bridging this knowledge gap was considered to be time-consuming. Class teachers' lack of competency in special education issues was also commented on, as well as the special education teachers' own perceived need for further education, particularly concerning research on bilingualism and bilingual development. Furthermore, the class teachers' lack of knowledge concerning special education issues was not found to be easily overcome by collaborative work, as the special education teachers did not find that they had sufficient time to provide all teachers with this type of knowledge in satisfactory ways. This is notable, considering the important role that special education services play in achieving inclusion for all children (see Thygesen et al., 2011).

In general, bilingualism was seen as something positive and as a resource for the bilingual students in the teachers' narratives. For example, the special education teachers knew that several of their newly arrived students received study guidance (see previous section on bilingual education policy in Sweden) and the teachers found that it represented an important language learning practice where the students could work with vocabulary both in their first language and in Swedish. Teacher Rasmus also described the role of study guidance as a necessity in order to prepare the newly arrived students to 'come into the system', referring to the Swedish educational system. Study guidance is, however, a practice separated from special education services in Swedish schools, and there was no collaboration between study guidance teachers and special education teachers.

\section{Conclusion}

Although bilingualism was seen as a resource by the teachers, both bilingual students and monolingual Swedish-speaking students were considered to be treated more or less identically in terms of literacy support and dyslexia-screening procedures. For example, training of phonological awareness, phoneme-grapheme mapping and reading - in Swedish only - appeared as frequently used methods to facilitate development of literacy skills. Here, the teachers' reliance on what constitutes 'good practice' perhaps reflects the dyslexia research literature's emphasis on training of phonological awareness, reading fluency, phoneme-grapheme mapping as well as 
reading comprehension; in this literature, possible uses of the bilingual children's various languages are seldom discussed or brought into focus. The teachers did not primarily express qualitative differences concerning their support to bilingual students but rather referred to lack-of-time issues. With regard to dyslexia identification procedures, teacher Malin did, however, question the use of diagnostic reading tests in Swedish that were 'made for speakers of Swedish'. In addition, teacher Rasmus acknowledged the need for first-language support for newly arrived students, referring to the established, although restricted, study guidance for newly arrived students. However, as this L1 subject support is separated from the special education services, a 'language divide' prevails where the use of the students' other languages remains limited to certain pedagogical practices and where special education support is not included. This is problematic considering that it may imply inadequate language educational and learning opportunities for bilingual students with dyslexia.

It is important to note that it may have been difficult for the teachers to give examples of language educational needs for such a heterogeneous group as 'bilingual students', for example, to know or express how to support bilingual students with various proficiency levels in Swedish, due to the various premises for learning. But the teachers' similar focus on their educational support may also be reflective of the notion of difference blindness (Kubota, 2004; cf. Lindberg, 2009), where a tendency to downplay differences could reflect a desire to treat the bilingual students equally regardless of origin and to not stigmatize the students (Runfors, 2009; see also Taylor, 1999). Teachers who are possibly reluctant to discuss particular language educational needs of second language learners may therefore act in accordance with this logic. But a consequence could be, contrary to its good intention - and contrary to the language education policy expressed in the curriculum - a bias against the bilingual students with dyslexia regarding literacy support within the special education services. That is, as such a pedagogical 'monolingual master model' (Mortimore et al., 2012) tends to overlook both the particular educational needs of students for the acquisition of, and learning through, Swedish as a second language as well as steps to augment literacy development in minority languages. Whether the teachers' narratives in this study in fact reflected difference blindness on individual bases may, however, be put into question. For example, the teachers' narratives were most likely governed by practical and structural possibilities and constraints. That is, although the teachers would have liked to work with texts and words in the students' first language as well as use additional dyslexia-screening procedures in other languages than Swedish, they seemed to have very few possibilities to implement this. It is also important to note that the special education teachers strongly advocated collaborative work with other teachers, above all with mother tongue teachers. Collaboration with mother tongue teachers was thought to facilitate and validate the process of dyslexia identification in bilingual students as well as to gain a more comprehensive picture of the bilingual students' language and literacy competencies and language use. In other words, although the teachers expressed 
significant practical and structural obstacles to collaborating with mother tongue teachers, this type of teamwork was still identified as necessary.

The teachers' emphasis on this type of collaboration could be viewed not only as a practical and pedagogically well-motivated solution to the identified language educational needs but also as a contestation of a pedagogical 'monolingual master model' and as a vital step to augment biliteracy development in bilingual students with dyslexia. Furthermore, changes in educational practices, such as the emergence of assessment and teaching materials in various minority languages, as well as an increased number of minority language-speaking teachers, would also most likely have a positive impact on bilingual students' biliteracy development. Likewise, the teachers' narratives indicate that mother tongue teachers need to be better integrated within schools and special education services. That would increase the potential benefits of a wider language focus in accordance with the bilingual education policy expressed in the curriculum as well as in accordance with L2 research on literacy development and learning (e.g. Cummins, 2000). Such a wider focus would also ideally encompass an increased awareness of bilingual development and learning, as well as of special education issues, among teachers in general.

The current study, however, has limitations considering its small-scale and narrow focus on interview data only. To further clarify and validate the results outlined above, it would therefore be desirable to conduct studies in which interview data are supplemented by ethnographic field data, such as classroom observation of pedagogical activities and interaction, which would allow for more in-depth analyses of current teaching practices aimed for bilingual students with dyslexia (cf. Borg, 2006). It would also be of interest to design intervention studies or action research with the potential to generate new knowledge and insights about these teaching practices as well as to improve them.

\section{Acknowledgements}

This research was funded by Stiftelsen Clas Groschinskys Minnesfond (SF1438) and Stiftelsen Kempe-Carlgrenska Fonden. The authors are also indebted to Jeanette Toth for correcting our English.

\section{References}

Abrahamsson, N., \& Bylund, E. (2012). Andraspråksinlärning och förstaspråksutveckling i en andraspråkskontext [Second language learning and first language development in a second language context]. In K. Hyltenstam, M. Axelsson \& I. Lindberg (Eds.), Flerspråkighet: en forskningsöversikt [Multilingualism: A research overview] (pp. 153-246). Vetenskapsrådets rapportserie 5. Stockholm: The Swedish Research.

Axelsson, M., \& Magnusson, U. (2012). Forskning om flerspråkighet och kunskapsutveckling under skolåren [Research on bilingualism and knowledge development during the school years]. In K. Hyltenstam, M. Axelsson \& I. Lindberg (Eds.), Flerspråkighet: en forskningsöversikt [Multilingualism: A research overview] (pp. 247-368). Vetenskapsrådets rapportserie 5. Stockholm: The Swedish Research.

Bagga-Gupta, S. (2004). Challenging understandings in pluralistic societies. Language and culture loose in school sites and losing sight of democratic agendas in Swedish education? Utbildning och demokrati, 13(3), $11-36$.

Borg, S. (2006). Teacher cognition and language education: Research and practice. London, England: Continuum. 
Bøyesen, L. (2008). Lesing og leseproblemer innen forskjellige ortografier [Reading and reading difficulties in different orthographies]. NOA norsk som andrespråk, 23(1), 32-54.

Busch, B. (2014). Building on Heteroglossia and heterogeneity: The experience of a multilingual classroom. In A. Blackledge \& A. Creese (Eds.), Heteroglossia as practice and pedagogy (pp. 21-40). New York: Springer.

Clandinin, D. J., \& Connolly, F. M. (2001). Narrative inquiry: Experience and story in qualitative research. San Francisco, CA: Jossey-Bass.

Cline, T., \& Reason, R. (1993). Specific learning difficulties (dyslexia): Equal opportunities issues. British Fournal of Special Education, 20, 30-34.

Cummins, J. (1979). Linguistic interdependence and the educational development of bilingual children. Review of Educational Research, 49, 222-251.

Cummins, J. (2000). Language, power and pedagogy: Bilingual children in the crossfire. Clevedon, England: Multilingual Matters.

Deponio, P., Landon, J., Mullin, K., \& Reid, G. (2000). An audit of the processes involved in identifying and assessing bilingual learners suspected of being dyslexic: A Scottish study. Dyslexia, 6(1), 29-41.

Dockrell, J. E., \& Lindsay, G. (2001). Children with specific speech and language difficulties: The teachers' perspective. Oxford Review of Education, 27(3), 369-394.

Elbro, C., Daugaard, H. T., \& Gellert, A. S. (2012). Dyslexia in a second language? A dynamic test of reading acquisition may provide a fair answer. Annals of Dyslexia, 62(3), 172-185.

Emanuelsson, I. (2001). Reactive versus proactive support coordinator roles: An international comparison. European Fournal of Special Needs Education, 16(2), 133-142.

Fouganthine, A. (2012). Dyslexi genom livet. Ett utvecklingsperspektiv på läs- och skrivsvårigheter [Dyslexia throughout the life-span. A developmental perspective on reading and writing difficulties] (Doctoral thesis). Department of Special Education, Stockholm University, Stockholm.

Frederickson, N., \& Frith, U. (1998). Identifying dyslexia in bilingual children: A phonological approach with inner London Sylheti speakers. Dyslexia, 4(3), 119-131.

Ganuza, N., \& Hedman, C. (under review). The impact of mother tongue instruction on the development of biliteracy - evidence from Somali-Swedish bilinguals.

Ganuza, N., \& Hedman, C. (2015). Struggles for legitimacy in mother tongue instruction in Sweden. Language and Education, 29(2), 125-139.

Gellert, A. S., \& Elbro, C. (in press). Does a dynamic test of phonological awareness predict early reading difficulties? A longitudinal study from Kindergarten through grade 1. Fournal of Learning Disabilities. doi: http://dx.doi.org/10.1177/0022219415609185

Geva, E., \& Wade-Woolley, L. (2004). Issues in the assessment of reading disability in second language children. In I. Smythe, J. Everatt \& R. Salter (Eds.), International book of dyslexia: A cross-language comparison and practice guide (pp. 195-206). Chichester: Wiley.

Gibbons, P. (2002). Scaffolding language, scaffolding learning. Teaching second languages in the mainstream classroom. Portsmouth, NH: Heinemann.

Gogolin, I. (1994). Der monolinguale Habitus der multilingualen Schule. Münster: Waxmann-Verlag.

Gough, P., Hoover, W., \& Peterson C. (1996). Some observations on the simple view of reading. In C. Cornoldi \& J. Oakhill (Eds.), Reading comprehension difficulties (pp. 1-13). Mahwah, NJ: Lawrence Erlbaum.

Gus, S., \& Samuelsson, S. (2002). Intelligence and dyslexia: Implications for diagnosis and intervention. Scandinavian fournal of Psychology, 40(2), 127-134.

Haglund, C. (2005). Social interaction and identification among adolescents in multilingual suburban Sweden. A study of institutional order and sociocultural change (Doctoral thesis). Centre for Research on Bilingualism. Stockholm University, Stockholm.

Hedman, C. (2009). Dyslexi på två språk. En multipel fallstudie av spansk-svensktalande med läs- och skrivsvårigheter [Dyslexia in Two Languages. A Multiple Case Study of Spanish-Swedish Speaking Adolescents with Reading and Writing Difficulties] (Doctoral thesis). Centre for Research of Bilingualism, Stockholm University.

Hedman, C. (2012). Profiling developmental dyslexia in bilingual Spanish-Swedish adolescents. Fournal of Speech-Language Pathology, 14(6), 509-519.

Hunter, S. V. (2009). Analysing and representing narrative data: The long and winding road. Current Narratives, 2, 44-54.

Hyltenstam, K., \& Milani, T. (2012). Flerspråkighetens sociopolitiska och sociokulturella ramar [The Socio-Political and Socio-Cultural Frames of Multilingualism]. In K. Hyltenstam, M. Axelsson \& I. Lindberg (Eds.), Flerspråkighet: en forskningsöversikt [Multilingualism: A research overview] (pp. 17-152). Vetenskapsrådets rapportserie 5. Stockholm: The Swedish Research Council. 
Kroskrity, P. V. (2006). Language ideologies. In A. Duranti (Ed.), A companion to linguistic anthropology (pp. 496-517). Malden, MA: Blackwell.

Kubota, R. (2004). Critical multiculturalism and second language education. In B. Norton \& K. Toohey (Eds.), Critical pedagogies and language learning (pp. 30-52). Cambridge, UK: Cambridge University Press.

Kulturdepartementet [Ministry of Culture]. (2009). Språklagen, SFS 2009:600 [The Language Act, SFS, 2009:600]. Stockholm: Kulturdepartementet.

Lindberg, I. (2009). I det nya mångspråkiga Sverige [In the new multilingual Sweden]. Utbildning E Demokrati, 18(2), 9-37.

Lyon, G. R., Shaywitz, S. E., \& Shaywitz, B. A. (2003). A definition of dyslexia. Annals of Dyslexia, 53, 1-14.

Meynert, M. J. (2014). Inclusive education and perceptions of learning facilitators of children with special needs in a school in Sweden. International fournal of Special Education, 29(2), 1-18.

Miller Guron, L., \& Lundberg, I. (2003). Identifying dyslexia in multilingual students: Can phonological awareness be assessed in the majority language? fournal of Research in Reading, 26(1), 69-82.

Morgan, E. (2014). Undervisningsmodeller som gynnar flerspråkiga elever: studiehandledning $i$ grundskolan [Teaching models favoring multilingual students: Study guidance in compulsory school]. Rapporter om utbildning 1. Fakulteten för lärande och samhälle, Malmö: Malmö högskola.

Mortimore, T., Hansen, L., Hutchings, M., Northcote, A., Fernando, J., Horobin, L., \& ... Everatt, J. (2012). Dyslexia and multilingualism: Identifying and supporting bilingual learners who might be at risk of developing $S p L D / d y$ slexia. British Dyslexia Association and the Lottery Fund. Research Reports for External Bodies. Bracknell, UK: The British Dyslexia Association.

Myrberg, M. (2007). Dyslexi - en forskningsöversikt [Dyslexia-A research overview]. Rapportserie 2: 2007. Stockholm: Vetenskapsrådet.

Nilholm, C. (2007). Forskningen om specialpedagogik. Landvinningar och utvecklingsvägar [Research in special educational needs. Gains and developmental paths]. Pedagogisk Forskning $i$ Sverige, 12(2), 96-108.

Nilsson, J., \& Axelsson, M. (2013). 'Welcome to Sweden': Newly arrived students' experiences of pedagogical and social provision in introductory and regular classes. International Electronic fournal of Elementary Education, 6(1), 137-164.

Phil, J. (2010). Etnisk mangfold $i$ skolen. Det sakkyndige blikket [Ethnic diversity in school. The gaze of the expert]. Oslo: Universitetsforlaget.

Runfors, A. (2009). Modersmålssvenskar och vi andra. Ungas språk och identifikationer i ljuset av nynationalism [Mother tongue Swedes and the rest of us. Adolescents' language and identifications in the light of new nationalism]. Utbildning $\mathcal{E}$ Demokrati, 18(2), 105-126.

Shakkour, W. (2014). Cognitive skill transfer in English reading acquisition: Alphabetic and logographic languages compared. Open fournal of Modern Linguistics, 4, 544-562.

Skolverket [The Swedish National Agency for Education]. (2008). Med annat modersmål - elever grundskolan och skolans verksamhet [With another mother tongue - students in compulsory school]. Rapport 321. Stockholm: Skolverket.

Stanovich, K. E. (1994). Annotation: Does dyslexia exist? Fournal of Child Psychiatry, 35(4), 579-595.

Statens beredning för medicinsk utvärdering: SUB [Swedish Council on Health Technology Assessment]. (2014). Dyslexi hos barn och ungdomar. Tester och insatser. En systematisk litteraturöversikt [Dyslexia in children and adolescents. Tests and interventions. A systematic literature review]. Gul rapportserie nr 225. Stockholm: Statens beredning för medicinsk utvärdering: SUB.

Statistics Sweden. (2014). Yearbook of Educational Statistics 2014. Stockholm: Statistiska centralbyrån. URN:NBN:SE:SCB-2013-UF01BR1301_pdf.

Sunderland, H., Klein, C., Savinson, R., \& Partridge, T. (1997). Dyslexia and the bilingual learner: Assessing and teaching adults and young people who speak English as an additional language. London: Language and Literacy Unit.

Takala, M., \& Ahl, A. (2014). Special education in Swedish and Finnish schools: Seeing the forest or the trees? British Fournal of Special Education, 41(1), 59-81.

Taylor, C. (1999). Det mångkulturella samhället och erkännandets politik [The multicultural Sweden and the politics of acknowledgement]. Göteborg: Daidaos.

Thygesen, R., Briseid, L. G., Tveit, A. D., Cameron, D., \& Kovac, V. B. (2011). Er generell pedagogisk kompetanse tilstrekkelig for å sikre en inkluderende skole? [Is general education competency sufficient to ensure an inclusive school?]. Norsk Pedagogisk Tidsskrift, 95(2), 104-114.

Utbildningsdepartementet [Ministry of Education and Research]. (2007). Skolförordning, SFS 2007:638 [The Ordinance for Compulsory School, SFS 2007:638]. Stockholm: Utbildningsdepartementet. 


\section{N. Falali-Moghadam and C. Hedman}

Utbildningsdepartementet [Ministry of Education and Research]. (2010). Skollagen, SFS 2010:800 [The Swedish Education Act, SFS 2010:800]. Stockholm: Utbildningsdepartementet.

Utbildningsdepartementet [Ministry of Education and Research]. (2011). Skolförordning, SFS 2011:185 [The Ordinance for Compulsory School, SFS 2011:185]. Stockholm: Utbildningsdepartementet.

Utbildningsdepartementet. (2013). Utbildning för nyanlända elever [Education for newly arrived students]. Ds: 2013:6. Stockholm: Utbildningsdepartementet.

Verhallen, M., \& Schoonen, R. (1993). Lexical knowledge of monolingual and bilingual children. Applied Linguistics, 14(4), 344-363.

Verhoeven, L., \& van Leeuwe, J. (2012). The simple view of second language reading throughout the primary grades. Reading and Writing, 25(8), 1805-1818.

Ziegler, J., \& Goswami, U. (2005). Reading acquisition, developmental dyslexia, and skilled reading across languages: A psycholinguistic grain size theory. Psychological Bulletin, 131(1), 3-29. 